УДК 378

DOI $10.21661 / \mathrm{r}-130032$

\title{
М.М. Юркова
}

\section{ТВОРЧЕСКОЕ САМОВЫРАЖЕНИЕ КАК ОДНО ИЗ УСЛОВИЙ ПОДГОТОВКИ УЧИТЕЛЯ К ВОСПИТАТЕЛЬНОЙ РАБОТЕ В ШКОЛЕ}

Аннотация: в статье отображена роль творческого самовыражения при подготовке студента-педагога к воспитательной работе, представлен инструментарий развития и раскрытия творческих способностей студентов, способствующчх их подготовки к работе в школе.

Ключевые слова: вуз, познавательно-креативная деятельность, профессиональное самовыражение, самостоятельная деятельность, студент, творческое самовыражение, учебное занятие, учебно-воспитательный процесс, учитель технологии, экспериментальные исследования, творческая работа.

\section{M.M. Yurkova}

\section{CREATIVE EXPRESSION AS ONE OF THE CONDITIONS OF TEACHER TRAINING FOR EDUCATIONAL WORK AT SCHOOL}

Abstract: the article shows the role of creative self-expression in the preparation of a student-teacher for educational work, a toolkit for the development and disclosure of the creative abilities of students contributing to their preparation for work at the school.

Keywords: higher education institution, cognitive-creative activity, professional self-expression, independent activity, student, creative self-expression, training session, teaching and educational process, technology teacher, experimental research, creative work.

Введение. Школе нужен учитель, который имеет профессиональную педагогическое образование и мастерски владеет своим предметом, направляет свою работу в русло постоянного творческого поиска, стремится к профессиональному совершенствованию. Такой учитель сможет создать условия для предоставления должного внимания личности воспитанника, развития его интеллектуальных, духовных, эстетических и нравственных способностей и его 
саморазвития, самореализации, самоутверждения, что и обусловило актуальность исследования.

Цель данной статьи - раскрыть роль творческого самовыражения студентапедагога в его готовности к работе в школе и методологию развития его самовыражения при обучении в вузе.

Опыт работы учебных заведений свидетельствует о том, что учитель, особенно в начале самостоятельной деятельности недостаточно проявляет свой творческий потенциал в разных видах деятельности. Большинство студентов, как показывает практика, демонстрируют низкий уровень творческого самовыражения профессионально значимых качеств. По нашему мнению, творческое самовыражения профессионально значимых качеств студентов - будущих учителей технологии - это уровень проявления таких психологических особенностей, которые обеспечивают их всестороннее развитие и саморазвитие, способствуют их утверждению, обеспечению значимых творческих потребностей.

При таких условиях творческое самовыражение будущих учителей технологии - это процесс создания в учебно-воспитательном процессе вуза педагогического заведения таких психолого-педагогических условий, которые способствуют активному усвоению теоретических знаний и практических умений по основам педагогического творчества в процессе личностно ориентированного развивающей взаимодействия в системе «преподаватель-студент», развития творческих личностных качеств будущего учителя [1, с. 64].

Итак, осмысление сущности творческого самовыражения как педагогической категории связано с выявлением взаимосвязи субъектов учебновоспитательной деятельности (преподавателей и студентов), способностью педагогического процесса насытить жизнедеятельность субъектов энергией, душевным напряжением, особым стилем взаимоотношений при обнаружении творческих особенностей.

Творческое самовыражения будущих учителей технологии - это способность, благодаря которой личность достигает жизненных успехов. 
Заметим, что творческое самовыражения играет роль внутреннего стимулирования студентов - будущих учителей технологии в условиях высшего педагогического заведения и является лучшим средством их самоутверждения на основе врожденного влечения ко всему новому.

Принципы творческого самовыражения студентов-педагогов пронизывают все звенья учебного процесса - процесс познания, осмысления, восприятия, закрепление, практического применения полученных знаний, умений и навыков [2, c. 95].

Таким образом, процесс творческого самовыражения будущих учителейпедагогов включает психологическую готовность, теоретическую подготовку (системно развитое обобщенное представление о творчестве, о проблеме ее развития, которое отображается с позиций общих и существенных характеристик), практическую подготовку (умение применять творческий подход в педагогической деятельности).

Процесс творческого самовыражения в будущих учителей-педагогов в условиях высшего педагогического заведения должен проходить поэтапно:

1) подготовительный, на котором происходит зарождение идеи;

2) вызревание - студент накапливает, концентрирует знания;

3) озарение - это главный, специфически творческий момент, когда человек сознательно или бессознательно работает над материалом, интуитивно «схватывает» ожидаемый результат;

4) проверка и доработка - это этап необходим, чтобы убедиться в том, что создано именно то, что было задумано, чтобы творение было совершенным $[3$, c. 24].

По нашему мнению, содержание учебно-воспитательного процесса должно быть наполнено в основном творческой деятельностью студентов и включать следующие основные элементы их познавательно-творческого взаимодействия:

- побудительные-мотивационная работа (студенты не только воспринимают мотивационные и целевые объяснения преподавателя, но и самостоятель- 
но конструируют собственные мотивы, определяют личные цели и задачи работы на пространстве указанного учебного занятия);

- первичное усвоение теоретического материала (обучающиеся, во время лекции, объяснения нового материала с помощью различных механизмов творческой деятельности учащихся переоформляют, трансформируют в соответствии с собственным пониманием и степенью готовности определения основных понятий, толкование закономерностей, обобщений, составляют проблемные, эвристические вопросы к теме и т. п.);

- самостоятельная проблемно-поисковая деятельность по осмыслению и углубление новых теоретических знаний (студенты обращаются к определенным источникам, чтобы ответить - устно или письменно - на конкретные проблемные вопросы;

- самостоятельная репродуктивная, поисковая, эвристическая работа заключающаяся в систематизации и обобщении ведущих знаний и умений, способов творческой деятельности (собственный творческий образовательный продукт);

- итоговая самостоятельная эвристическая или креативная работа (по выбору) как создание личностно значимого творческого продукта, качество которого становится решающим при диагностике и оценке усвоения учебного занятия - коррекция выполненной итоговой творческой работы (по желанию автора) с целью совершенствования и получения высшей оценки [4, с. 140].

На всех этапах обучения (теоретическом, экспериментальном, методическом), среди которых лекционные, семинарские, практические занятия, самостоятельная, индивидуальная работа, консультации, коллоквиумы, конкурсы, педагогическая практика, обеспечивается активное взаимодействие студентов и преподавателей как субъектов учебно-воспитательного процесса посредством дидактических возможностей [5, с. 142]. Так, проведение лекционных, практических, семинарских занятий в различных формах творческой организации обучения, среди которых дискуссия, диспут, деловая игра, проблемное консультирование, способствуют выявлению творчества у будущих педагогов. Да- 
же лекция, если сопровождаться проблемными вопросами, анализом, синтезом, словесным и схематичным обобщением новой информации, собственно формулировки и толкования определений, законов, противоречий, закономерностей, различных научных подходов, интерпретацией одного понятия и явления, обеспечивает творческое осмысление нового учебного материала при изучение каждого учебного занятия.

Особенно эффективными для творческого самовыражения студентовпедагогов являются виды самостоятельной познавательно-креативной деятельности, а именно: такие как написание рефератов, сочинений, педагогические рассказы студентов; доклады; создание презентаций, проектов современных уроков, обобщающих схем, таблиц, графиков, алгоритмов; решения профессиональных задач; выполнения проблемных задач; подготовка стенгазет; составление тестов, перечень вопросов.

Необходимо заметить, что профессиональному самовыражению будущих учителей способствует и активная научная деятельность, которая заключается в самостоятельном проведении экспериментальных исследований, написании рефератов, курсовых, дипломных, магистерских работ, тезисов, статей, участия в конференциях (внутривузовских, региональных, всероссийских, международных). Кроме научной работы, росту творческого потенциала также способствуют участие в конкурсах, олимпиадах, поэтических чтениях, тематических вечеpax, в празднованиях, днях самоуправления.

Стоит заметить, что необходимо привлекать всех студентов к творческой работе, предоставлять им возможность выбирать самостоятельно тот или иной вид деятельности или помогать в выборе продукта творческого самовыражения, учитывая индивидуальные и психические особенности каждого.

Вывод. Обобщая вышесказанное, можно сделать вывод, что творческое самовыражения будущих учителей-педагогов- это целенаправленный, осознанный высоко-результативный процесс творческого саморазвития личности (самообразования, самовоспитания, самосовершенствования, саморегуляция, 
самооценка) и рост ее замыслов, творческих способностей, умений, потребностей, мотивов, жизненных ценностей.

Основной задачей преподавателей во время учебно-воспитательного процесса является создание свободной атмосферы, направленной на обеспечение комфортности общения, уверенности в своих силах, творческих потенциях, а также использование необходимых методов, приемов, методик, форм, видов учебной деятельности, направленной на творческое самовыражения будущих студентов учителей технологии в условиях высшего педагогического учебного заведения, учитывая их индивидуальные и психические особенности.

\section{Сиисок литературы}

1. Василькова Ю.В. Социальная педагогика: Курс лекций: Учебное пособие для студентов пед. вузов и колледжей / Ю.В. Василькова, Т.А. Василькова. - М.: Академия, 1999.

2. Воспитательная деятельность педагога / Под общ. ред. В.А. Сластенина, И.А. Колесниковой. - М.: Академия, 2005. - 336 с.

3. Выготский Л.С. Педагогическая психология. - М.: Педагогика, 1991. $318 \mathrm{c}$.

4. Педагогика профессионального образования: Учеб. пособие / Е.П. Белозерцев, А.Д. Гонеев, А.Г. Пашков [и др.]; под ред. В.А. Сластенина. М.: Академия, 2004. - 368 с.

5. Профессионально-культурное становление студента в образовательном процессе / Отв. ред. В.В. Игнатова, О.А. Шушерина. - Томск: изд-во Томск. госуд. ун-та, 2005. - 264 с.

Юркова Марина Михайловна - педагог дополнительного образования МБОУ ДОД «Судакский центр детского и юношеского творчества» г.о. Судак, Республика Крым, Судак; магистрант Крымского инженерно-педагогического университета ФГАОУ ВО «Крымский федеральный университет им. В.И. Вернадского», Республика Крым, Симферополь. 
Yurkova Marina Mikhailovna - supplementary education teacher MBEI of SEC "Sudak Center of Children and Youth Creativity" of Sudak city, the Republic of Crimea, Sudak; graduate student at the Crimean Engineering and Teacher Training University FSBEI of HE "V.I. Vernadsky Crimean Federal University", the Republic of Crimea, Simferopol. 